\title{
Visceral Afferent Neuron
}

National Cancer Institute

\section{Source}

National Cancer Institute. Visceral Afferent Neuron. NCI Thesaurus. Code C33877.

A cell that conducts a nerve impulse that originated at a receptor in one of the interior organs of the one of the three cavities of the body and proceeds towards the central nervous system. 